\title{
THE CONSTITUTIONALITY OF THE CALIFORNIA TRUSTEE'S SALE
}

It is common practice in California for a debtor, particularly the purchaser of real property, to secure his obligation by a deed of trust under which the property purcliased is given as security for payment of the debt. The deed of trust includes a power of sale which empowers the trustee to sell the property in the event of default by the trustor (the debtor) and apply the proceeds of the sale to the obligation. The trustee acts on the instructions of the beneficiary of the deed of trust (the creditor), and the relationship between them is not a fiduciary one. Legal title to the property rests in the trustee, the deed of trust is recorded, and no court action is required for the trustee to convey valid title to a third party. ${ }^{1}$ The conduct of a sale under the power in a deed of trust is regulated in California by Civil Code sections 2924$29241 .^{2}$ If the debtor argues that the sale was wrongful and in violation of the underlying contract, he may seek the intervention of the courts either to restrain the sale or to have it set aside after it is held.

Since the decision of the United States Supreme Court in Sniadach v. Family Finance Corporation, ${ }^{3}$ which held that prejudgment garnishment of a debtor's wages is unconstitutional, numerous decisions of state and federal courts at all levels have held various creditor recovery procedures unconstitutional as violative of the debtor's right to notice and an opportunity for a hearing before his property is taken from him. ${ }^{4}$ These decisions have called into question the constitu-

1. Throughout this Comment references will be made to the trustee as the one who formally takes action to enforce the terms of the deed of trust. However, it must be remembered that the trustee acts only on instructions from the beneficiary, and it is the latter who makes all decisions as to what action will be taken.

2. CAL. CIV. CODE $\$ \S 2924-2924 h$ (West Supp. 1973).

3. 395 U.S. 337 (1969).

4. Fuentes v. Shevin, 407 U.S. 67 (1972); Lynch v. Household Finance Corp., 405 U.S. 538, rehearing denied, 406 U.S. 911 (1972); Bell v. Burson, 402 U.S. 535 (1971); Goldberg v. Kelly, 397 U.S. 254 (1970); Adams v. Egley, 338 F. Supp. 614 (S.D. Cal. 1972); Lebowitz v. Forbes Leasing \& Fin. Corp., 326 F. Supp. 1335 (E.D. Pa. 1971); Santiago v. McElroy, 319 F. Supp. 284 (E.D. Pa. 1970); Klim v. Jones, 315 F. Supp. 109 (N.D. Cal. 1970); Laprease v. Raymours Furniture Co., 315 F. Supp. 716 (N.D.N.Y. 1970); Jones Press, Inc. v. Motor Travel Serv., Inc., 286 Minn. 205, 176 N.W.2d 87 (1970); Larson v. Fetherston, 44 W.2d 712, 172 N.W.2d 20 (Wis. 1969). California cases following Sniadach are: Rios v. Cozens, 7 Cal. 3d 792, 499 P.2d 979, 103 Cal. Rptr. 299 (1972); Randone v. Appellate Dep't, 5 Cal. 3d 536, 488 P.2d 13, 96 Cal. Rptr. 709 (1971); Blair v. Pitchess, 5 Cal. 3d 258, 486 P.2d 1242, 96 Cal. Rptr. 42 (1971); Cline v. Credit Bureau, 1 Cal. 3d 909, 464 P.2d 125, 83 Cal. Rptr. 669 (1970); McCallop v. Carberry, 1 Cal. 3d 905, 464 P.2d 122, 83 Cal. Rptr. 666 (1970); Kruger v. Wells Fargo Bank, 31 Cal. App. 3d 202, 107 Cal. 
tionality of many creditor remedy devices. This Comment will examine whether the private sale procedure carried out in accordance with the contract between the parties (the deed of trust) and under the California statutory provisions violates constitutional due process requirements of notice and opportunity for hearing.

The California courts of appeal have been uniform in their decisions that the procedure is constitutional. ${ }^{5}$ Recently, however, two trial courts have refused to give effect to sales by a trustee under the power of sale as violative of the debtor's right to due process of law. ${ }^{\circ}$ It seems clear that the validity of the California trustee's sale provision will remain in dispute until the supreme court determines the question. $^{\text {? }}$

The constitutionality of the trustee's sale depends on the extent to which the notice and hearing provided for the debtor under the present procedure are sufficient when the court balances the interests of the debtor, the creditor, and the state. ${ }^{8}$ If the remedies available to the debtor offer a rational resolution of these often competing interests, the court should hold that the legislative determination that sales may be held by a trustee under a power of sale in a security instrument should

Rptr. 133 (1st Dist. 1973); Quebec v. Bud's Auto Service, 32 Cal. App. 3d 257 (2d Dist. 1973), reh. granted, June 1, 1973; Mihans v. Municipal Court, 7 Cal. App. 3d 479, 87 Cal. Rptr. 17 (1st Dist. 1970).

5. Strutt v. Ontario Savings \& Loan Ass'n, 28 Cal. App. 3d 866, 105 Cal. Rptr. 395 (4th Dist. 1972); MCA, Inc. v. Universal Diversified Enterprises Corp., 27 Cal. App. 3d 170, 103 Cal. Rptr. 522 (2d Dist. 1972); Strutt v. Ontario Savings \& Loan Ass'n, 11 Cal. App. 3d 547, 90 Cal. Rptr. 69 (4th Dist. 1970); Lopez v. Bell, 207 Cal. App. 2d 394, 24 Cal. Rptr. 626 (2d Dist. 1962); Lancaster Security Inv. Corp. v. Kessler, 159 Cal. App. 2d 649, 324 P.2d 634 (2d Dist. 1958).

6. Great Western Savings \& Loan Ass'n v. Jackson, No. 676242, San Francisco Muni. Ct. (1972); Mann v. JBR Dev. Co., No. 54581, Ventura County Super. Ct. (1972). In the Jackson case, the trial judge stated that the principles of the Randone decision forced "the conclusion that the requirements of procedural due process are not met in the case of sales pursuant to powers of sale contained in deeds of trust. This is true notwithstanding the strict comphiance (as was done by plaintiff lender here) with all the requirenrents of the subject code sections." (Letter of Judge John J. Hopkins, to counsel for the plaintiff and defendant, October 13, 1972.) The defendant in that case had not received notice that the trustee considered her in default and intended to sell the property.

7. For a discussion of the Texas statute providing for foreclosure under the power of sale see Comment, Due Process Evolution: Fuentes and the Deed of Trust, 26 Sw. L.J. 876 (1972). See also, Comment, Power of Sale Foreclosure After Fuentes, 40 U. CHr. L. Rev. 206 (1972).

8. The Supreme Court in Fuentes v. Shevin, 407 U.S. 67 (1972), pointed out that the due process requirements of prior notice and an opportunity for hearing, as elucidated in Sniadach and Goldberg, are not confined to situations where the debtor is threatened with the loss of property which may be considered a necessity of life. $I d$. at 88. The Court said: "It is enough to invoke the procedural safeguards of the Fourteenth Amendment that a significant property interest is at stake, whatever the ultimate outcome of a hearing on the contractual right to continued possession and use of the goods." Id. at 87. 
be given effect. ${ }^{9}$ This Comment will analyze the interests of the parties and of the state, as well as the detriments to the trustor which result from the use of the private sale rather than judicial foreclosure, in an atteinpt to determine whether the procedure represents a state policy to which the court can defer.

I.

\section{State Action}

In order for the requirements of the due process clause to affect the legality of the trustee's sale, the court inust find sufficient state involveinent to bring the procedure within the provisions of the fourteenth amendment. ${ }^{10}$ Direct state action is not required; sufficient state action may be found in statutes which either coinpel or permit private action which violates due process requireinents. ${ }^{11}$

9. In Fuentes v. Shevin, 407 U.S. 67 (1972), the Court said that the ultimate right to continued possession of goods depended on whether the debtors had defaulted on their contractual obligations and that the simplicity of the issue might afect the kind of hearing whicl the debtor must have an opportunity to obtain. The Court plainly did not mean that the debtor must have a full trial on the merits in every case. The Conrt said: "[S]ome form of notice and hearing-fornal or inforinal-is required before deprivation of a property interest that 'cannot be characterized as de minimis." "Id. at 90 n.21. There is no requirement that the creditor instigate action in a court, so long as the debtor has sufficient notice of the impending action to seek the court's intervention if he has defenses to the creditor's action. See notes 67-74 infra and accompanying text.

10. No State shall make or enforce any law which shall abridge the privi-

leges or immunities of the citizens of the Umited States; nor shall any State

deprive any person of life, liberty, or property, without due process of law; nor deny to any person within its jurisdiction the equal protection of the laws.

See 42 U.S.C. § 1983 (1971); Adickes v. S. H. Kress \& Co., 398 U.S. 144 (1970); Reitınan v. Mulkey, 387 U.S. 369 (1967).

11. In Reitinan v. Mulkey, 387 U.S. 369 (1967), the Supreine Court refused to give effect to an Article of the California Constitution which prohibited the state from denying the right of any person to sell, lease, or rent his real property to such persons as he umight in his absolute discretion choose. The Court found that there was significant state involvement in private discrimination, so as to amount to unconstitutional state action. A prohibited state involvement thus can be found where the state can bo charged only with encouraging rather than compelling discrimination. See Klim v. Jones, 315 F. Supp. 109 (N.D. Cal. 1970), where the courts refused to give effect to the California Innkeepers' Lien Law, CaL. Civ. CoDe $\S 1861$ (West 1970), on the ground that the landlord had the power to impose the lien and seize the property only by virtue of the statute. See also Quebec v. Bud's Auto Service, 32 Cal. App. 3d 257, 261-63 (2d Dist. 1973), reh. granted, June 1, 1973.

In Adams v. Egley, 338 F. Supp. 614 (S.D. Cal. 1972) (appeal pending in the Court of Appeals for the Ninth Circuit) the district court held that repossession of property under the provisions of $\$ \S 9503$ and 9504 of the California Comunercial Code has sufficient elements of state involvement to require application of the due process requirements of notice and hearing, since the action is taken under color of state law. (There is still room for debate, lowever. See Messenger v. Sandy Motors, Inc., 295 A.2d 402 (N.J. 1972), holding that action under $\$ 9.503$ of the Uniform Commercial Code does not constitute state action within the fourteenth amendment. $C f$. 
Although older federal cases have found insufficient state involvement in the state's requiring compliance with the statute, ${ }^{12}$ this solution of the question does not seem satisfactory. The statutes governing nonjudicial sale under a deed of trust represent a coercive formulation of the state's policy favoring the private sale. Together, the statutes providing for both judicial and nonjudicial foreclosure actions are complementary expressions of state policy toward real property security ${ }^{13}$ which provide flexibility sufficient to meet varying needs of changing security situations. ${ }^{14}$ The provisions which circumscribe private sale foreclosure and determine the rights and obligations of the parties (Civil Code sections 2924-2924h) have been recognized as a "compreliensive legislative scheme designed to provide adequate proteetion to the borrower against forfeitures." 15

California state statutes permit the trustor to confer the power of sale on the truste ${ }^{16}$ and regulate the conduct of the sale. ${ }^{17}$ The statute includes requirements for serving notice on the trustor when the trustee decides to sell because of default. ${ }^{18}$ These state limitations of the parties' freedom to contract with regard to the property hypothecated in the deed of trust reflect a strong state interest in the private foreclosure sale. It is important, however, to remember the limited nature

A. Dunham, Due Process and Commercial Law, 1972 SuP. CT. Rev. 135, 147-155.) See also Laprease v. Raymours Furniture Co., 315 F. Supp. 716 (N.D.N.Y. 1970). But cf. McCormick v. First Nat'l Bank, 322 F. Supp. 604 (S.D. Fla. 1971).

12. Curti v. Pacific Mortgage Guar. Co., 87 F.2d 42 (9th Cir. 1936); Davidow v. Lachman Bros. Inv. Co., 76 F.2d 186 (9th Cir. 1935).

13. Roseleaf v. Chierighino, 59 Cal. 2d 35, 378 P.2d 97, 27 Cal. Rptr. 873 (1963).

14. See the discussion in the text accompanying notes 133-52 infra.

15. Smith v. Allen, 68 Cal. 2d 93, 96, 436 P.2d 65, 66, 65 Cal. Rptr. 153, 154 (1968).

16. A power of sale may be conferred by a mortgage upon the mortgagee or any other person, to be exercised after a breach of the obligation for which the mortgage is a security.

CAL. Crv. Code \& 2932 (West 1970).

In Bank of Italy Nat'l Trust \& Savings Ass'n v. Bentley, 217 Cal. 644, 20 P.2d 940 (1933), the California Supreme Court affirmed that in this state the mortgage and the deed of trust are equal as security instruments: "The function and purpose of the two types of security are identical." Aside from the distinctions between the two forms of security device which were pointed out by the court in this case, the nortgage and deed of trust are treated similarly under the statutory scheme. A nortgage can contain a power of sale, just as the deed of trust does, and the same procedural requirements apply to both. This Comment refers only to the power of sale in a deed of trust; but the same arguments apply to nonjudicial foreclosure of a mortgage under a power of sale.

17. In R. G. Hamilton Corp., Ltd. v. Corum, 218 Cal. 92, 95, 21 P.2d 413, 414 (1933), the California Supreme Court said: "Section 2924 does not purport to provide a remedy, but to prescribe a certain limitation for the exercise of the contractual renedy."

18. CaL. Crv. Code $§ \S 2924-2924 h$ (West Supp. 1973). 
of the state action in this case. The state has chosen to permit a device for private dispute settlement. If either party feels that the issues in dispute cannot be settled privately, he still has recourse to the courts to obtain an adjudication of his rights. Where the trustor thinks the trustee is in breach of the agreement and is selling the property wrongfully, he may bring suit to enjoin the sale. The state has thus permitted private resolution of the problems raised by default on the obligation only when the trustor does not seek the court's protection of his rights. If the trustee's right to sale is disputed, the courts will give effect to the sale only after a determination that he is not selling wrongfully. There is no doubt that the power of sale confers a valid right to convey title, ${ }^{19}$ but the trustee can exercise that right only when the trustor is im default. If he attempts to sell the property absent default, the burden the trustor assumes of going to court to enjoin the trustee's conduct or to have the sale set aside is analogous to the burden on any aggrieved party-to seek the help of the courts in dispute settlement.

State action is also present in the form of judicial validation of the private sale upon proof of comphance with the procedures required by these statutes. ${ }^{20}$ Creditors have relied repeatedly on the courts to give effect to trustee's sales. Having used the state courts to enforce the state's policy as expressed in the statute, they should not now be heard to complain that the sale represents insufficient state action for the courts to apply due process notions of fairness in determining whether the sale should be given effect.

Finally, in providing facilities and services which assist the trustee in complying with the provisions of the statute, state action is present. The deed of trust, requests for notice of default, the notice of default, notice of sale, and ultimately the trustee's deed are recorded in the office of the recorder in the county where the property is located. Recordation means that the state is using its resources to provide notice of the agreement to anyone who wishes to find out the legal condition of the property and to furnish the protection of the recording acts to the parties to the agreement. Since this combination of legislative approval and regulation of the private sale and intervention of the courts in giving effect to the sale constitutes state action, both the procedures involved and the remedies available ${ }^{21}$ must provide sufficient

19. See CAL. Crv. CoDE $\S 2932$, quoted at note 16 supra. The trustee may sell the property, however, only "after a breach of the obligation for which the mortgage is a security."

20. See cases cited at note 5 supra, in which the district courts of appeal have given effect to private sales.

21. The statutory scheme does not provide for a hearing for the debtor; however, the debtor who wishes to contest the sale may avail himself of the traditional equitable powers of the court in an attempt to obtain an injunction, CAI. CoDs Crv. 
protection for the parties to comply with due process requirements for notice and opportunity for hearing.

II.

Notice

\section{A. The Mullane Standards}

By conferring a power of sale on the trustee, the trustor does not waive his right to notice of any proposed sale. ${ }^{22}$ In protection of that right, the state requires notice in some form to the trustor in the event of recordation of a notice of default and election to sell by the trustee. ${ }^{23}$ The United States Supreme Court has emphasized repeatedly the basic importance of notice in the procedural due process scheme. ${ }^{24}$

In Mullane v. Central Hanover Bank \& Trust $\mathrm{Co}^{25}$ the Court said:

Against [the] interest of the state we nnust balance the individual interest sought to be protected by the Fourteenth Amendment. This is defined by our holding that "The fundamental requisite of due process of law is the opportunity to be heard." . . . This right to be heard has little reality or worth unless one is informed that the

PRo. $\S \S 525-527$ (West Supp. 1973), or to set aside the sale. He may also defend himself in an unlawful detainer action brought by the purchaser at the sale. CAL. CoDe Crv. Pro. \& 1161a (West Supp. 1973). In order to prevent a conveyance to a bona fide purchaser, he may file a notice of lis pendens with the office of the recorder prior to the sale, thus giving constructive notice of the pending litigation to all prospective purchasers. CAL. CODE CIv. Pro. $\$ 409$ (West 1967). See discussion of actions available to debtor in text accompanying notes 75-132 and in note 162 infra.

22. The trustee's right to sell is operative only in the event of default. Conferring a private right of sale in no way subsumes a waiver of the debtor's constitutional right to notice and an opportunity for hearing before he is deprived of a significant property interest. In Fuentes v. Shevin, 407 U.S. 67 (1972), the Supreme Court rejected the argument that the conditional sales contracts signed by the debtors in that case were waivers of constitutional rights. "[T] he purported waiver provisions here are no more than a statement of the seller's right to repossession upon occurrence of certain events." Id. at 96.

A waiver of constitutional rights must be made knowingly and intelligently. Brady v. Umited States, 397 U.S. 742 (1970); Johnson v. Zerbst, 304 U.S. 458 (1938). The saine presumption against waiver of constitutional rights which is found in criminal cases operates in civil cases. Fuentes v. Shevin, 407 U.S. 67, 94 n.31 (1972). The terms of the deed of trust contain nothing to inform the trustor that he may be waiving a constitutional right.

23. CAL. Crv. CODE $\S 2924$ (West 1973).

24. Fuentes v. Shevin, 407 U.S. 67 (1972); Bell v. Burson, 402 U.S. 535 (1971); Goldberg v. Kelly, 397 U.S. 254 (1970); Sniadach v. Family Finance Corp., 395 U.S. 337 (1969); Walker v. City of Hutchinson, 352 U.S. 112 (1956); Mullane v. Central Hanover Bank \& Trust Co., 339 U.S. 306 (1950); Coe v. Armour Fertilizer Works, 237 U.S. 413 (1915).

25. 339 U.S. 306 (1950). 
matter is pending and can choose for himself whether to appear or default, acquiesce or contest. . . . An elementary and fundamental requirement of due process in any proceeding which is to be accorded finality is notice reasonably calculated, under all the circumstances, to apprise interested parties of the pendency of the action and afford them an opportunity to present their objections. . . . The notice inust be of such nature as reasonably to convey the required information . . ., and it must afford a reasonable time for those interested to make their appearance. . . . But if with due regard for the practicalities and peculiarities of the case these conditions are reasonably met the constitutional requirements are satisfied. ${ }^{26}$

In Mullane, the Court was talking about a judicial proceeding to settle a trustee's account. Such a situation is obviously different from the situation where a nonjudicial sale is noticed. ${ }^{27}$ However, because such a sale will be accorded finality, if the trustor does not protest, the same fairness requirements should apply. ${ }^{28}$

The requirement of notice to the debtor should serve to neutrahize the interests of the two parties by permitting the debtor to take action to obtain a hearing if he wishes to do so. Traditional fairness norms require at least this much, and enforcement of those norms is well within the court's competence. Notice which puts the parties on an equal footing is so important that the court should not defer to any legislative determination of what constitutes sufficient notice, such as that expressed in Civil Code section 2924, ${ }^{29}$ but rather should require constitutionally sufficient notice to the debtor. The Mullane notice requirements should be the standard, rather than something less. ${ }^{30}$

Once the debtor receives notice, the burden placed on him to act -which he has accepted by agreeing to the terms of the deed of trust-is not a burden of constitutional dimensions. ${ }^{31}$ Without no-

26. Id. at 314-15.

27. The trustee's account in Mullane could be settled only by a decree of the court; the trustee's notice under discussion in this Conment only informs the trustor that he intends to sell the property privately if the trustor does not intervene to stop him.

28. The state will use its processes to give effect to the salc, cither to confirm or deny its validity in the courts in the event of litigation, or in the use of its offices for recording the deed and attending to other aspects of the conveyance from the trustee to the purchaser.

29. $\S \S 2924 \mathrm{~b}$ and $2924 \mathrm{c}$ contam elaborate provisions for providing notice to the debtor, but if the debtor does not request notice, publication is sufficient to comply with the statute.

30. In Mullane the Court pointed out that "[t]he statutory notice [by publicationl to known beueficiaries is inadequate, not because in fact it fails to reach everyoue, but because under the circumstances it is not reasonably calculated to reach thosc who could easily be informed by other means at hand." 339 U.S. 306, 319 (1950). Cf. Schroeder v. City of New York, 371 U.S. 208 (1962) (posted notice of intent to divert a river inadequate when the property owner's lome and address could casily have been ascertained).

31. See discussion in notes 67-74 infra and accompanying text. 
tice, however, the debtor who beheves that he is not in default in the obligation, that lie lias made all payments due, and has fulfilled all other obhigations under the security instrument, will not be able to protect himself against the trustee's breach and wrongful sale because he may not know the property is to be sold until after the trustee has conveyed to a bona fide purchaser for value and without notice. If the trustor were aware of the trustee's intention, he could protect himself by filing suit for an injunction, filing a notice of lis pendens to prevent sale to a bona fide purchaser, ${ }^{32}$ or negotiating with the creditor for a private settlement of their differences.

\section{B. The Statutory Notice Provisions}

The notice provisions of the Civil Code must be ineasured against the Mullane standards. Under section 2924b, the trustee, mortgagee, or beneficiary who records a notice of default must send copies of the notice by registered mail to all persons who have recorded a request for notice. ${ }^{33}$ Although most trust deed forms include a request for notice by the trustor, there is no provision in the statute which requires that a copy of the notice be sent to the trustor whose property is being sold if he does not request it. Several cases have held that strict coinpliance with the letter of the statute is sufficient and that the trustee or beneficiary need not send notice to the trustor if no request was recorded. ${ }^{34}$ If the notice which is sent is returned, or if the trustee has actual knowledge that the trustor did not receive it, he is under no obligation to make additional efforts to give notice of his election to sell the property-even if he has knowledge of the whereabouts of the trustor and could contact him easily. As the Court in Mullane pointed out, opportunity for hearing is meaningless without notice. ${ }^{35}$ Because this is so, the trustee or beneficiary should be required to make every good faith effort to locate the trustor or mortgagor and give him actual notice that the notice of default has been recorded.

Civil Code section $2924 \mathrm{~b}$ additionally provides that if the trustor

32. For a discussion of the scope and validity of California's lis pendens provision, see note 162 infra.

33. CaL. Crv. Code $\S 2924 \mathrm{c}$ (West 1970).

34. Strutt v. Ontario Savings \& Loan Ass'n, 11 Cal. App. 3d 547, 90 Cal. Rptr. 69 (4th Dist. 1970); McClatchey v. Rudd, 239 Cal. App. 2d 605, 48 Cal. Rptr. 783 (4th Dist. 1966); Lopez v. Bell, 207 Cal. App. 2d 394, 24 Cal. Rptr. 626 (2d Dist. 1962) (copy of the notice of default returned unopened by the post office); Sugiyama v. Cuneo, 208 Cal. App. 2d 397, 25 Cal. Rptr. 348 (1st Dist. 1962); Lancaster Security Inv. Corp. v. Kessler, 159 Cal. App. 2d 649, 653, 324 P.2d 634 (2d Dist. 1958) (court specifically said actual notice not required).

35. "This right to be heard has tittle reality or worth unless one is informed that the matter is pending and can choose for himself whether to appear or default, acquiesce or contest." 339 U.S. 306, 314 (1950). 
does not include a request for notice in the deed of trust or does not record a request for notice, the notice of default must be publislied

once a week for four weeks in a newspaper of general circulation in the county in which the property is situated. ... In heu of such publication a copy of the notice of default may be delivered personally to the trustor or mortgagor within such 10 days or at any time before publication is completed. ${ }^{36}$

Mullane dealt with the adequacy of published notice of proceedings to settle a trustee's account. The Court there found that a published notice was inadequate when it was possible to mail notice to the beneficiaries of the trust. ${ }^{37}$ The Court conceded that published notice would have to suffice for those who could not be reached by mail, ${ }^{38}$ but pointed out that the interests of those beneficiaries who did not receive actual notice would be safeguarded by those with similar interests who were notified. ${ }^{39}$

In the situation of the trustee's sale, resort to published notice should almost never be necessary. When actual notice is possible sucl constructive notice should be inadequate. ${ }^{40}$ Many trustors do not live on the property which is lypothecated by the deed of trust. It is unlikely that they would see notice published in a newspaper of general circulation in the county where the property is located. Even if the trustor did read that particular newspaper, it would be easy to miss the notice, tucked away, as it would be, on a back page in small print. Unlike the Mullane situation, there is no other party who will protect the interests of the trustor who does not receive notice. ${ }^{41}$ Without notice, he will lose the benefits of the 90-day interval required before the trustee may file his notice of sale, ${ }^{42}$ during which time the trustor might lave reinstated the obligation by paying the amounts in default, ${ }^{43}$ refinanced the loan, or brought an action to enjoin the trustee froin selling the property.

The present provision for notice to the trustor or mortgagor under

36. CaL. Crv. Code $§ 2924 b$ (West 1970).

37. 339 U.S. 306,318 (1950).

38. Id. at 317 .

39. Id. at 319.

40. Cf. Schroeder v. City of New York, 371 U.S. 208 (1962).

41. See text accompanying note 39 supra.

42. CaL. Crv. Code $\$ 2924$ (West Supp. 1973).

43. During the three-month period provided by Civil Code $\S 2924$, the debtor may reinstate the obligation by paynent of the amounts in default. CAL. Crv. CODE $\$ 2924 c$ (West 1970). The obligation is not accelerated, and full tender is not required until the end of that period. Between the time when the trustee records his notice of sale and the time when the sale takes place, the debtor can redeen the property, but only on payinent of the entire obligation. Cf. CAL. Crv. CODE $\$ 2903$ (West 1970). 
Civil Code section $2924 \mathrm{~b}$ thus appears to be inadequate to ensure as nearly as possible that the debtor will know that the creditor intends to take action and thus be able to act to defend himself. There seems to be no good reason why this should be the case. The state has no countervailing interest which should permit it to assert that publication is more desirable simply because the trustor, through some oversight, has omitted to record a request for notice of default, and the interest of the debtor in receiving notice is particularly compelling. If the address on the trustor's request is out of date and the notice is returned, the trustee should not be absolved from further responsibility for providing notice. The burden on the trustee of taking additional action is slight when compared with the potential detriment to the debtor, ${ }^{44}$ and the creditor should not be permitted to gain the advantage of being able to act behind the debtor's back. The debtor who has requested notice in the deed of trust ${ }^{45}$ will think that he will be notified of the trustee's intention and will probably rely on this belief. The creditor should have to make reasonable efforts to supply such notice.

Under Civil Code section 2924f, the trustee or beneficiary must give 20 days' written notice of sale after expiration of the 90 -day period following recordation of the notice of default. ${ }^{46}$ Those who have recorded a request for notice of sale under section $2924 \mathrm{~b}$ must be sent notice, and, in addition, notice must be posted in a public place in the judicial district where the property will be sold, published once a week in a local newspaper, and posted in a conspicuous place on the property.

These provisions present the same problems as the notice of default. The statute should require that the trustee or beneficiary holding the sale send actual notice to the trustor, in addition to publication and posting of notice. These latter forms of notice will serve to notify the public that the sale will be held and thus encourage competitive bidding and a fair sale. The trustor should be assured of actual notice, however, so that he can use this last opportunity to enjom the sale or obtain financing to repay the loan. ${ }^{47}$ If the trustor has received no-

44. The debtor may lose his property, or he may be unable to set aside the sale without tendering the full amount of the obligation. If the trustee has conveyed to a bona fide purchaser, the BFP's equities may be so great that the sale will be conclusive as to him. If the trustor had received notice, he could have protected himself against a possible sale to a BFP by recording a notice of lis pendens. Car. Code Crv. Pro. \$ 409 (West 1967). For a discussion of the validity of section 409 (California's lis pendens provision), see note 162 infra.

45. CAL. CIV. CODE $\$ 2924 \mathrm{c}$ (West 1970).

46. Cal. Civ. Code $\$ 2924$ (West Supp. 1973).

47. Until the sale forecloses his equity of redemption, the trustor may redeem by paying the obligation. See note 43 supra. 
tice that the notice of default was recorded, the 20-day period should be sufficient for him to take additional steps to protect himself. ${ }^{48}$

\section{Reformation of the Notice Provisions}

In order to ensure that the trustor will receive a copy of the notice of default so that he can act to protect his rights in his property if he has defenses against the beneficiary's or trustee's action, the notice of default (and later the notice of sale) should, in effect, be "served" on the trustor, in the same manner and with the same formalities and safeguards required for service of process when an action is filed. ${ }^{49}$

Adequate notice to the trustor would be ensured if the Civil Code required that the trustee comply with the requirements of sections 415.10 through 415.50 of the Code of Civil Procedure. Since July 1970 personal service has not been required in a civil action in California..$^{50}$ Substituted notice is permitted by dehivering a copy of the summons and complaint to the defendant's place of business, office, or place of residence, leaving it with a responsible person over the age of 18 , and mailing a copy of the summons and complaint to the defendant at the same address where copies were delivered." Al Alternatively, a summons and complaint may be served by mail with provision for acknowledgment of receipt to be made by the defendant. ${ }^{52}$ Service by publication is permitted under certain conditions, but only if "it appears to the satisfaction of the court in whicl the action is pending that the party to be served cannot with reasonable diligence be served in another manner specified by this article." ${ }^{33}$ This provision for constructive service by publication takes care of the situation in which the

48. If the trustor did not act in response to the notice of default, either because he hoped to persuade the trustee not to sell the property or because he hoped to be able to reinstate the obligation, CAL. CIv. CoDE $\$ 2924 c$ (West 1970), receipt of the notice of sale may cause him to act. He may still have time to obtain a preliminary injunction against the sale, and he can prevent sale to a bona fide purchaser by recording a notice of lis pendens. See note 44 supra and note 162 infra. Cf. Young v. Ridley, 309 F. Supp. 1308, 1311 (D.D.C. 1970), holding that 30 days' notice gave homeowner ample time to seek remedies. When the trustor in California receives a copy of the notice of sale, a period of three months has alrady elapsed during which he could have sought remedies through the courts or through private negotiations.

49. Cal. Code Civ. Pro. \$\$ 415.10-415.50 (West Supp. 1973).

It would be appropriate for the legislature to consider amendment of the statute to require that the notice of default "served" on the debtor include a statement that he should seek advice of an attorney for counsel concerning his rights. Lack of such a provision, however, does not speak to the constitutionality of the statute.

50. The present provisions for service of process were effective as of July 1 , 1970 .

51. Cal. Code Civ. Pro. $\$ 415.20$ (West Supp. 1973).

52. Cal. Code Civ. Pro. $\$ 415.30$ (West Supp. 1973).

53. Cal. Code Crv. Pro. $\$ 415.50$ (West Supp. 1973). 
trustor attempts to hide out and make it impossible for the trustee to locate him and notify him of his intention to sell the property.

Since no action is pending in any court when the notice of default is filed, ${ }^{54}$ and thus the trustee cannot obtain an order of court as to the method of service most reasonably calculated to give notice, it seems appropriate that the trustee should bear the risk of nonpersuasion, in any subsequent proceeding instituted by the trustor, to show that publication was resorted to only because the trustor could not be served by any other method despite reasonably diligent efforts. However, in determining whether the trustee has successfully carried this risk of nonpersuasion the court should take into account the fact that presumably the debtor is aware that he is in default and that it is likely that the trustor will make an election to sell the property. ${ }^{55}$

If the statutory requirements for service of process are met by providing the trustor with a copy of the notice of default and notice of sale, and if the trustee or beneficiary is forced to carry the risk of nonpersuasion in showing that service was made by publication only as a last resort, the creditor will no longer be able to take advantage of the debtor's possible ignorance of the impending sale to plan a strategy whereby the property would be sold without notice. The parties would thus be placed on a more equal footing, and any unfair advantage given to the creditor under the present scheme (under which it is sometimes possible to comply strictly with the statute but still not give actual notice to the debtor) would be removed.

In cases where the debtor has received notice, and thus where the statutory provisions are adequate to protect the debtor, no constitutional problem is presented. However, where the trustee has been able to avoid giving notice, despite the fact that he could easily have notified the trustor of his intent to sell, the trustor has been deprived

54. The beneficiary may have started a judicial foreclosure action in order to obtain a receiver. CAL. CoDe CTV. Pro. $\$ 564(2)$ (West 1967). In such a case the trustor or mortgagor has an opportunity to present available defenses in that action, and he should routinely seek an injunction against nonjudicial sale of the property if he has defenses against the trustee's claims. However, in a case where the trustee or mortgagee anticipates that the trustor will present valid defenses, it is unlikely that he would risk beginning a foreclosure action. Under the present system, he could hope to use the notice requirements provided by statute to avoid giving actual notice and hope that the trustor would not learn of the impending sale. The trustee should not be permitted to use the judicial foreclosure action as a blind, letting the trustor assume that that is the only action the trustee intends to take, while the latter sells the property nonjudicially without providing actual notice of his intent.

55. Since the remedies of injunction and setting aside the sale are both equitable remedies, the court may adjust the rights of the parties if the debtor has not received notice. Since in most cases the trustor does receive notice under the statutory procedure (unless he is trying to avoid notice while knowing that he is in default), the notice provisions will not present a problem in most cases. 
of the notice and hence the opportunity for hearing which are his constitutional rights. ${ }^{56}$ In such cases, the court should take lack of notice into account in considering whether to void the sale..$^{57}$ It would be advisable for the legislature to eliminate this problem by amending the statute to require actual notice whenever possible.

III.

\section{HEARING}

\section{A. The Due Process Standard}

In Fuentes v. Shevin ${ }^{58}$ the Supreme Court said:

"Parties whose rights are to be affected are entitled to be heard; and in order that they may enjoy that right they must first be notified." .... It is equally fundamental that the right to be heard "inust be granted at a meaningful time and in a meaningful manner."

After receiving notice, the debtor nust be able to choose "whether to appear or default, acquiesce or contest." 60 Recent cases, decided by the United States Supreme Court, by the lower federal courts, and by the California Supreme Court, have demied effect to procedures which the courts held violated the debtor's rights to procedural due process because he was deprived of his property without notice or hearing. ${ }^{\text {BI }}$

The case of the trustee's sale does not go so far in overreaching the debtor. The cases following Sniadach v. Family Finance Corporation $^{62}$ have relied on Justice Harlan's statement in his concurring opinion that the Court premised its decision on the debtor's deprivation of the use of his wages when they were garnished by the creditor before judgment. ${ }^{63}$

1 To determine whether the California scheme of debtor protections in the case of the private sale complies with the constitutional requirement of an opportumity for a hearing, it is necessary to take into

56. The Supreme Court has said: "If the right to notice and a hearing is to serve its full purpose, then, it is clear that it must be granted at a time when the deprivation can still be prevented." Fuentes v. Shevin, 407 U.S. 67, 81 (1972). If the trustor is not notified until after the sale has taken place, presumably when the purchaser brings an action in unlawful detaimer, CaL. CoDe Crv. Pro. $\$ 1161$ a (West Supp. 1973), he runs a risk of losing the property and being forced to seek a remedy against the trustee after he has been evicted from his property.

57. See the discussion of setting aside the sale in the text accompanying notes 117 to 132 infra.

58. 407 U.S. 67 (1972).

59. Id. at 80 [citations omitted].

60. Mullane v. Central Hanover Bank \& Trust Co., 339 U.S. 306, 314 (1950).

61. See cases cited at note 4 supra.

62. 395 U.S. 337 (1969).

63. Id. at 342 (Harlan, J., concurring). 
account two factors: the time of the hearing, to determine whether the hearing is provided before the debtor loses the use of the property; and the manner of the hearing, to decide if the debtor's opportunity to present his case and refute the claims of the trustee is constitutionally adequate.

\section{B. Time for Hearing-The Opportunity To Be Heard}

The recordation of the notice of default, accompanied by notice to the debtor of the trustee's election to sell the property to satisfy the obligation, does not deprive the trustor of the use of the property. $\mathrm{He}$ is entitled to remain in possession until after the sale, and during this period he has several opportumities to seek relief in the courts if he believes that the trustee's sale will be wrongful and in violation of the underlying contract between the parties. ${ }^{64}$ Any deprivation claimed would not even approach that of prejudgment attachment of the property, ${ }^{65}$ since the debtor has specifically hypothecated the property as security for his debt and could not dispose of the property free of the security interest in any event.

The trustee's recording of the notice of default, therefore, does not deprive the debtor of any rights in the property which he previously enjoyed. The trustee's action is taken in accordance with the provision of the contract between the parties that permits the trustee to sell in the event of default. To the extent that the trustor disagrees

64. By suit for injunction and motion for a preliminary injunction. CAL. CODE Civ. Pro. $\$ \$$ 525-527 (West Supp. 1973).

65. There is soine question as to whether prejudgment attachment of real property by an unsecured creditor constitutes a taking of property within the meaning of Sniadach. In Randone v. Appellate Dep't 5 Cal. 3d 536, 544-545 n.4, 488 P.2d 13, 18 n.4, 96 Cal. Rptr. 709, 714 n.4 (1971), the California Supreme Court said:

Because the attachment of real estate does not generally deprive an owner of the use of his property, but inerely constitutes a hen on the property, the "taking" generated by such attachment is frequently less severe than that arising from other attachments. In view of this basic difference in the effect of such attachment, it has been suggested that a statute which dealt solely with the attachmeut of real estate might possibly involve coustitutional considerations of a different inagnitude than those discussed hereafter.

See also Note, Attachment in California: $A$ New Look at an Old Writ, 22 STAN. L. REv. 1254, 1277 (1970).

It is certainly arguable, however, that attachment of real property before judgment deprives the debtor of the use of his property in the sense that he cannot sell it free from the attachment. If the creditor had originally chosen to be unsecured, he should not later be able to secure the debt by attaching the property without having to prove his case in court. This is particularly true in California, where deficiency judgment legislation creates certain disadvantages for the secured creditor; prejudgment attachment would permit the unsecured creditor to have the best of both worlds. See also Idaho First Nat'l Bank v. Rogers, 41 U.S.L.W. 2492 (Idaho Dist. Ct., Feb. 21, 1973), holding prejudgment attachment of real property unconstitutional on the basis of due process considerations of Sniadach v. Family Finance Corp., 395 U.S. 337 (1969) and Fuentes v. Shevin, 407 U.S. 67 (1972). 
with the trustee's determination that a default exists, he has the remedies available which exist for any aggrieved party who wishes to complain of a contract breach.

\section{Manner of Hearing-An Appropriate Hearing}

By authorizing the contracting parties to place a power of sale in the contract, ${ }^{66}$ the state has not expressed a policy favoring a procedure which denies the debtor a hearing. The fact that the provisions of Civil Code section 2924 et seq. speak only to notice requirements, and not to any requirement for a hearing, reflects a legislative determination that the trustor's opportunity to seek relief in the courts is adequate, not a determination that the trustor is not entitled to a hearing.

The granting of the remedies available to the trustor, a suit for injunction or to set aside the sale, is within the discretion of the court. The legislature has deferred to the courts in conferring these remedies on the trustor in the event of wrongful sale. The balancing of interests which the courts do before granting equitable relief is uniquely within their competence. To argue that the remedies available are so inadequate as to be a denial of constitutional due process is to say that the legislature should provide greater protection to the trustor than is conferred by the equitable powers of the courts. However, the courts seem fully capable of ensuring that the debtor is not deprived of his property without due process of law. The case-by-case adjustment of the conpeting interests of the parties is one which courts have traditionally handled, and the legislature niay safely delegate to them the responsibility to protect the debtor's constitutional rights.

To determine if this legislative judgment satisfies due process requirements for the trustor's protection, the competing interests of the parties must be examined in light of the state's policies and its balancing of those interests to decide if the decision is one to which the courts can defer as a rational expression of policy which does not unduly burden either party.

Requiring the trustor to initiate an action challenging the propriety of the trustee's sale does not make the burden on the trustor to seek a learing appropriate to his theatened interests one of constitutional proportions. Only when a state seeks to suppress sone highly valued constitutional right, such as freedoni of speech, ${ }^{67}$ lias the United States Supreme Court found initiation of litigation to be an unconstitutional burden. The government nust neet a high standard of proof before

66. See Car. Crv. CoDe $\S 2932$, note 13 supra.

67. Cf. Healy v. James, 408 U.S. 169, 184 (1972); Blount v. Rizzi, 400 U.S. 410, 417 (1971); Oregon v. Mitchell, 400 U.S. 112, 238 (1970); Freedman v. Maryland, 380 U.S. 51 (1965). 
it can deprive a citizen of his free speech interests. ${ }^{68}$ Further, the interest of all citizens freely to exercise their right to speak is vindicated, in part, by not requiring a person to validate his claims to that right, absent strong initial evidence by the government that suppression is justified.

The trustee's sale involves a private contract between two parties and a claim by one that the other has breached. The two parties are equally capable of asserting their contractual rights. Unlike a speaker claiming his first amendment freedoms, the trustor does not have a constitutional right to injunctive rehef from an announced intention of the trustee to exercise a term of the contract. He does have a due process riglit to notice and an opportunity for an appropriate hearing; but this right is preserved by the sale procedures.

In formulating procedural standards for the notice and hearing required prior to deprivation of a property interest, the Supreme Court has left unquestioned that part of the procedures at issue which requires the claimant to come forward to effectuate his hearing. ${ }^{69}$ Moreover, in a civil suit of the kind which would be involved either if the trustee pursued judicial foreclosure or if the trustor sued to enjoin the sale, the burden of proof placed on the trustor would be similar. ${ }^{70}$ The question of the availability of an appropriate hearing thus seenus to hinge not on whether the trustor is a defendant or a plaintiff, but rather on what issues he can raise in the hitigation, ${ }^{71}$ and on what bur-

68. See, e.g., Speiser v. Randall, 357 U.S. 513,523 (1958), where the Court said that allocation of the burden of proof is a constitutional matter when it involves a constitutionally protected right.

69. See, e.g., Bell v. Burson, 402 U.S. 535 (1971), Goldberg v. Kelly, 397 U.S. 254 (1970). In Goldberg, New York had incorporated in its administrative code provisions of HEW's regulations specifying the requirements for a fair hearing. 397 U.S. at $259 \mathrm{n.4}$. These provisions specify that a welfare claimant must be notified of his right to a hearing, 45 C.F.R. $\$ 205.10$ (a)(2) (1972), and require that hearings be provided to those individuals requesting it. Id., $\$ 205.10(\mathrm{a})(3)$. The Court did not require that New York initiate a hearing absent such a request.

In Bell, provisions of the Georgia statutes and regulations permited the Director of Public Safety to suspend a person's license and vehicle registration. 402 U.S. at 536 n.1. GA. CODE ANN. \$ 92A-602 (1958) requires the Director to provide for a hearing upon request. At such a hearing, the driver might attempt to convince the Director that his case fell within one of the exceptions to the suspension statute, including, inter alia, "if, prior to the date that the Director would otherwise suspend license . . . there shall be filed with the Director evidence satisfactory [to show that the person has been released from liability or will prevail in a tort action against him]." GA. CoDe ANN. \$ 92A-605(c)(6) (Supp. 1970). In Bell, the Court found insufficient the questions which Georgia allowed to be placed at issue in such a hearing, 402 U.S. at 541 , but did not otherwise object to the procedural or evidentiary structure of the hearing.

70. See discussion in the text accompanying notes 102 and 129 infra.

71. See Bell v. Burson, 402 U.S. 535, 541 (1971), and note 69 supra. 
dens are placed on him to maintain the action. ${ }^{72}$

If the trustee were required in every instance to obtain the approval of the court before conducting a sale, there would be an cffective end to nonjudicial foreclosure in California. If due process required the trustee to initiate an action before exercising the power of sale one would then be forced to decide whether a full trial on the merits is required - in which case nonjudicial and judicial foreclosure become identical -or something less. ${ }^{73}$ The present situation already provides the trustor with an opportunity for a hearing; to the extent that this is adequate (and subsequent discussion will attempt to show that it is) there seems no reason to reach this question and demand yet another bureaucratization of the action of private parties. ${ }^{74}$

\section{Suit for Injunction \\ a. The Nature of the Hearing}

The trustor can take advantage of his opportumity for a hearing by initiating an action to enjoin the trustee's sale ${ }^{75}$ and moving for a preliminary injunction to prevent the sale pending a trial on the merits of his claim. ${ }^{78}$ Because the injunction is an equitable remedy, the court can take into account the relative weight of the competing inter-

72. Placing substantial burdens on the trustor before he can pursue an action to vindicate his claims might be characterized as denying him an opportunity for hearing, rather than raising questions of its appropriateness, but analytically the same issues must be addressed regardless of the characterization. For a discussion of the burdens placed on the trustor in an injunction action or a suit to set aside the sale, see notes 96-116 infra and accoinpanying text.

73. The Supreme Court has not been explicit in its statements as to what kind of hearing is required in each case. In Mullane v. Central Hanover Bank \& Trust Co., 339 U.S. 306, 313 (1950), the Court said the hearing inust be "appropriate to the nature of the case." In Boddie v. Connecticut, 401 U.S. 371, 378 (1971), the Court said: "The formality and procedural requisites for the hearing can vary, dcpending upon the innortance of the interests involved and the nature of the subsequent proceedings." Accord, Bell v. Burson, 402 U.S. 535, 541-42 (1972). In light of the state's rational determination that the remedies available to the trustor provide a sufficient opportunity for a hearing, the burden rests on the challenger to show that the hearings available to the trustor do not ineet constitutional requirements. On standards for hearing, see generally, Comment, Financial Responsibility Laws in Constitutional Perspective, 61 CAIIF. L. REv. 1072, 1085-1104 (1973).

74. To require that the trustor obtain a court's decision on whether he may carry out his sale would place additional burdens on the court system. Such a result seems needless, since the trustor who has no defenses to the sale has no reason to demand an adjudication of his rights, and one who has defenses will seek his rcmedy. If it is claimed that the unsophisticated debtor will not have sufficient courage to challenge the trustor by seeking the intervention of the courts, one answer is that that same individual would probably take a default judgment rather than obtaining a lawyer to answer the trustor's complaint for foreclosure.

75. CAL. CODE CIV. Pro. $\S \S 525-526$ (West 1967).

76. Cal. Code CTv. Pro. \$ 527 (West Supp. 1973). 
ests of the parties in determining whether to grant a preliminary injunction.

Generally, a preliminary injunctive order does not reach the nerits of the permanent injunctive rehef sought in the complaint. The court, at this stage, balances the equities of the parties and determines whether the defendants should be restrained from exercising the right claimed pending a trial on the merits. The general purpose is to preserve the status quo until the merits of the action are determined. The court considers who will bear the greater injury should the preliminary injunction be granted and whether a reasonable probability exists the plaintiff will prevail. ${ }^{77}$

In the course of valuing the interests of the parties, the court can consider the nature of the asset which the debtor stands to lose in the event a sale takes place. If the debtor were a homeowner whose only substantial asset is his home, his unique interest probably would outweigh the creditor's claim, which is for money owed, and hence fungible. The court can then grant the preliminary injunction to prevent the substantial loss which would result and which would not be compensable in damages.

The court can also take into account the adhesiveness of the trust deed as evidenced by the unequal bargaining power of the creditor and the borrower. This consideration would also favor the homeowner, who probably had no choice in conferring a power of sale on the trustee in order to obtain financing for his home. At the other end of the spectrum is the large commercial purchaser to whom these considerations may not apply at all, and there are numerous other borrowers to whom they apply in different degrees. It is peculiarly within the equitable discretion of the court to take all these factors into account when considering whether to grant the injunction.

In D. H. Overmyer Co. v. Frick ${ }^{78}$ the Supreme Court gave effect to an Ohio statute authorizing the use of cognovit notes containing confession of judgment clauses. In its decision the Court relied heavily on the relative bargaining power which the parties were able to exercise, ${ }^{79}$ as well as the ease with which the judgment could be reopened. $^{80}$

In Swarb v. Lennox, ${ }^{81}$ the Court affirmed a federal district court decision that the confession of judgment provisions of cognovit notes

77. State Bd. of Barber Examiners v. Star, 8 Cal. App. 3d 736, 738, 87 Cal. Rptr. 450, 451 (4th Dist. 1970). See also Continental Baking Co. v. Katz, 68 Cal. 2d 512, 528, 439 P.2d 889, 898-99, 67 Cal. Rptr. 761, 770-71 (1968); Flavio v. McKenzie, 177 Cal. App. 2d 274, 279, 2 Cal. Rptr. 79, 83 (1st Dist. 1960).

78. 405 U.S. 174 (1972).

79. Id. at 186 .

80. Id. at 188.

81. 405 U.S. 191 (1972). 
authorized by a Pennsylvania statute could not be given effect against debtors with annual incomes of less than $\$ 10,000$.

Both these decisions indicate that the courts are aware of and troubled by unconscionable overreaching of the debtor by a creditor who dictates the terms of the agreement. Furthermore, they both evidence the court's ability to appraise sucl factors in reaching decisions whicli affect the interests of the parties. There is no reason to claim that the California courts cannot do the same thing when determining whether or not to issue an injunction against a sale by a trustee in a particular situation.

Indeed, the case-by-case determination of the right to an imjunction inay be preferable to a blanket rule. Courts are competent to review facts and make individual determinations, and are better able to suit each judgment to the peculiar circumstances of the parties than is the legislature when it drafts a statute applicable to all. Historically, the legislature has relied on the courts to perform this function, and the parties may be assured it will be done fairly.

Code of Civil Procedure section 527 requires that the party seeking a preliminary injunction inust "show satisfactorily" that he is entitled to it. ${ }^{82}$ The California Supreme Court recently interpreted this requirement as follows:

[T] he court will consider the probability of the plaintiff's ultimately prevailing in the case and, it has been said, will deny a preliminary injunction unless there is a reasonable probability that plaintiff will be successful in the assertion of his rights. ${ }^{83}$

In determining the question of what constitutes a reasonable probability, the court can, of course, take into account the fact that the plaintiff probably will not have lad time to obtaim discovery, ${ }^{84}$ as well as any other considerations which may affect the trustor's preparedness for the suit.

The granting or denial of a preliminary injunction is within the

82. CaL. Code Crv. Pro. $\$ 527$ (West Supp. 1973).

83. Continental Baking Co. v. Katz, 68 Cal. 2d 512, 528, 439 P.2d 889, 899, 67 Cal. Rptr. 761, 771 (1968). A "reasonable probability" standard of proof is a less stringent standard than either "more probable than not" or "clear and convincing," which standards the debtor would have to meet in a judicial foreclosure or other form of final adjudication if private sales were abolished. This lower standard for the showing required to enjoin the sale clearly does not place a burden on the trustor which is so onerous that it reaches constitutional dimensions. Compare the standards for hearing approved by the Supreme Court in Fuentes v. Shevin, 406 U.S. 67, 97 (1972), quoted in text accompanying note 101 infra.

84. Ten days' notice is required before a deposition may be taken. Cal. Codr Civ. Pro. \$ 2019 (West Supp. 1973). The order to show cause will probably be returned before discovery is available. See Cal. Code Civ. Pro. $\$ 527$ (West Supp. 1973). 
sound discretion of the trial court. ${ }^{85}$ However, the courts of appeal will review an abuse of discretion:

Discretion is abused in the legal sense "whenever it may be fairly said that in its exercise the court in a given case exceeded the bounds of reason or contravened the uncontradicted evidence." $" 86$

In most cases, however, the plaintiff can rely on the trial court to examine all the aspects of the case and reach a reasonable conclusion as to whether a preliminary injunction should be granted. ${ }^{87}$ To argue that the trustee's sale is unconstitutional on the ground that it denies the trustor an opportunity for an adequate hearing, thereby implying that the injunctive remedy is inadequate, is to say that the courts are not able to adjust the rights of the parties in an equitable way. ${ }^{88}$ How-

85. Continental Baking Co. v. Katz, 68 Cal. 2d 512, 527, 439 P.2d 889, 898, 67 Cal. Rptr. 761, 770 (1968); Flavio v. McKenzie, 177 Cal. App. 2d 274, 278-79, 2 Cal. Rptr. 79, 83 (1st Dist. 1960).

If the trial court fails properly to exercise its discretion and does not take into account all the considerations which influence a debtor's right to a preliminary injunction, the hearing for the preliminary injunction may deprive him of the constitutionally mandated hearing. Of course, in the event that these factors do not appear to have been fully considered at trial, the courts of appeal should review for abuse of discretion.

86. Continental Baking Co. v. Katz, 68 Cal. 2d 512, 527, 439 P.2d 889, 898, 67 Cal. Rptr. 761, 770 (1968).

87. A different situation exists with regard to sales by national banks because the debtor can not enjoin a sale under the power of sale in a deed of trust if the beneficiary is a national bank. "[N]o attachment, injunction, or execution shall be issued against [a national bank] or its property before final judgment in any suit, action, or proceeding in any State, county, or municipal court." 12 U.S.C. § 91 (1971). Judicial construction of the statute has made it clear that its application is not confined to cases of actual or contemplated insolvency, but rather it "bars the interim remedy in state courts as to any national bank." Kemple v. Sec. First Nat'1 Bank, 249 Cal. App. 2d 719, 57 Cal. Rptr. 838 (1st Dist. 1967); First Nat'l Bank of Oakland v. Superior Court, 240 Cal. App. 2d 109, 49 Cal. Rptr. 358 (1st Dist. 1966), rehearing denied, cert. denied, 385 U.S. 829 (1966).

The trustor is not prohibited from commencing an action for declaratory relief against the national bank, however, and if the trustor also files a notice of his pendens, (see note 162 infra), no purchaser would be able to obtain title insurance and for all practical purposes the sale will be forestalled. The trustor still lias the additional tool of an equitable action to set aside the sale after it has been leeld, which remedy does not fall within the statutory exclusion. See 28 U.S.C. $\$ 1348$ (1971), which provides: "All national banking associations shall, for the purposes of all other actions by or against thein, be deemed citizens of the States in which they are respectively located." See also Continental Nat'l Bank v. Buford, 191 U.S. 119 (1903), and First Nat'l Bank of Oakland v. Superior Court, supra. The notice of lis pendens serves to preserve the trustor's remedies by preventing conveyance to a bona fide purchaser for value. See discussion of setting aside the sale in text accompanying notes 117 to 132 infra.

88. In Lindsey v. Normet, 405 U.S. 56 (1972), the Umited States Supreme Court gave effect to provisions of an Oregon forcible entry and unlawful detainer statute which called for trial within six days of filing the complaint and limited the triable issues to the one of default. The Court said that the provisions did not violate due process on their face and were not invalid because they might deprive the tenant of a proper hearing in soine situations. Id. at 65 . The tenant's remedy on his other 
ever, this balancing role is one in which the courts have traditionally engaged. The competing interests of the parties may be safely entrusted to the court's sound discretion. ${ }^{80}$

In his suit for an injunction, the trustor will often rely on a claim for an offset against the amount due on the obligation. The claim for offset may explain why the trustor las stopped making payments on the obligation and thus is considered in default by the trustee. Claims that cross-deinands for money liave been compensated are now governed by Code of Civil Procedure section $431.70 .^{90}$ The language of the present statute seems to limit the availability of the claim of offset or compensation to the defendant and to make the claim unavailable to the trustor who is plaintiff in a suit for an injunction or to set aside the sale.

There is evidence, however, that the legislature did not intend such a result when the statute was amended. The Legislative Committee Comment ${ }^{11}$ on the statute cites with approval a 1954 case, Hauger v. Gates, ${ }^{02}$ in which the California Supreme Court permitted plaintiffs in a suit to set aside to claim a set-off in an amount exceeding the amount due on their note. The court said:

Section 440 makes it clear that plaimtiffs' right of set-off was available without the necessity of bringing an independent action setting forth the related dealings between the parties. . . . It would not be reasonable, as contended by defendants, to imterpret section 440 of the Code of Civil Procedure so as to permit the right of setoff in a foreclosure action under a deed of trust and yet to deny such right

claims was to institute another action against the landlord. Id. at 66. The trustor in California can litigate the issue of default in the hearing on his motion for a preliminary injunction. If he is withholding payments because of other disagreements with the trustee or the beneficiary, but cannot make a showing of reasonable probability that he will prevail on these other claims, see note 83 supra, his remedy, after he has cured his default, is to litigate those issues in another action, something he has ample time to do within the 90-day statutory period. CAL. Civ. CoDe $\$ 2924$ (West Supp. 1973). If the trustor is in default because he doesn't have the money to pay and can't obtain it through refinancing, the state has no constitutional obligation to allow hin to protract the litigation by raising additional issues. For the courts to pernnit the trustor to use the prelininary injunction in this way would be to rewrite the contract between the parties. Cf. Karlsen v. American Savings \& Loan Ass'n, 15 Cal. App. 3d 112, 92 Cal. Rptr. 851 (2d Dist. 1971).

89. See cases cited in notes 78-81 supra and accompanying text.

90. Where cross-demands for money have existed between persons at any point in time when neither demand was barred by the statute of limitations, and an action is thereafter commenced by one such person, the other person may assert in his answer the defense of payment in that the two demands are compensated so far as they equal each other. . . .

[Emphasis added.] CAL. CODE CIV. PRO. $\$ 431.70$ (West Supp. 1973).

91. For text of the legislative comment, see Deering's California Code of Civil Procedure, Annotation to Section 431.70 (Bancroft-Whitney 1972).

92. 42 Cal. 2d 752, 269 P.2d 609 (1954). 
where the foreclosure was attempted by extrajudicial sale thereunder. ${ }^{93}$

That the legislative comment cited Hauger with approval should indicate that offset and compensation continue to be available as an affirmative cause of action in situations in which the party claiming the offset appears as plaintiff. The present wording of the statute is probably an example of careless draftsmanship, and it might be advisable for the legislature to amend the statute to clarify its intent. Pending such clarification, however, it seems unlikely that a court would refuse to allow a plaintiff to hitigate the issue. If the trustor is in default because of a compensating claim against the beneficiary, such a refusal would effectively deny him a hearing on that issue and might raise constitutional problems. ${ }^{94}$ It seems likely, however, that the courts will continue to allow plaintiffs to use offset as a claim against the defendant, ${ }^{25}$ in which case the trustor's ability to place at issue all allegations which might affect the determination of whether a default exists is unimpaired.

\section{b. The Bonding Requirements}

In order to obtain a preliminary injunction, the plaintiff must post a bond in an anount to be determined by the court. This requirement is codified in Code of Civil Procedure section 527, ${ }^{96}$ and the courts have held that if the plaintiff does not post bond the preliminary injunction is invalid. ${ }^{27}$ The bond is required as a trade-off between the defendant who is enjoined from action pending a final determination on the merits, and the plaintiff who claims he would suffer irreparable harm if such conduct were not restrained. Because of the minimal showing required froin the plaintiff ${ }^{98}$ (when balanced against the degree of impending harm), it is reasonable to require that the plaintiff post a bond sufficient to compensate the defendant if the court later determines that an injunction should not be granted. ${ }^{90}$

93. Id. at $755,269 \mathrm{P} .2 \mathrm{~d}$ at 611 .

94. See note 88 supra, however.

95. The absence of litigation on this question since the statute became effective on July 1, 1970 indicates that the courts liave permitted claims for offset to be used under the new statute in the same way that they were under the old one.

96. Cal. Code Civ. Pro. \& 527 (West Supp. 1973). See also Cal. Code Ctv. PRo. §§ 1054 and 1054a (West 1967).

97. Oksner v. Superior Court, 229 Cal. App. 2d 672, 687, 40 Cal. Rptr. 621, 629 (2d Dist. 1964); Sachs v. Killeen, 165 Cal. App. 2d 205, 331 P.2d 735 (2d Dist. 1958).

98. See note 83 supra.

99. See note 162 infra for complementary provisions for an undertaking in order to expunge the trustor's notice of lis pendens. See also note 106 infra for a discussion of California's revised attachment statute, which also utilizes the bonding techmique to balance the interests of both parties. Insuring against potential loss of one party pending a decision on the merits is the traditional pattern. 
The Supreme Court in Fuentes v. Shevin ${ }^{100}$ said:

"[D]ue process is afforded only by the kinds of 'notice' and 'hearing' which are aimed at establishing the validity, or at least the probable validity, of the underlying claim against the alleged debtor before he can be deprived of his property. . ...101

The standard of proof required of the trustor in a hearing for preliminary injunction ${ }^{102}$ clearly meets this standard. The Court in Fuentes also said, however, "The nature and form of such prior hearings, 1noreover, are legitimately open to many potential variations and are a subject, at this point, for legislation-not adjudication." ${ }^{103}$ Since the hearing available to the debtor on his motion for a preliminary injunction provides him with a constitutionally adequate hearing, the legislature may make a rational determination that a bond is required before the injunction is granted.

In Lindsey $v$. Normet, ${ }^{104}$ the Supreme Court refused to give effect to an Oregon requirement to post double rent as bond on appeal from lower court decisions in unlawful detainer cases. The Court said, however, that a requirement that the tenant post bond in the amount of each month's rent would be constitutional because rationally related to the purpose of bond.

We do not question here reasonable procedural provisions to safeguard litigated property or to discourage patently insubstantial appeals, if these rules are reasonably tailored to achieve these ends and if they are uniformly and nondiscriminately applied.105

The California requirement of posting an injunction bond seems to satisfy these requirements: it safeguards the creditor's interest in the litigated property; it is required of all plaintiffs; and, moreover, the amount is determined by the trial judge in his discretion so that the small debtor will not be unreasonably deprived. ${ }^{106}$

The state does not statutorily impose an excessively onerous bond. If the trial court abuses its discretion and imposes a bond so great that it amounts to a taking of property without due process, the appellate

100. 407 U.S. 67 (1972).

101. Id. at 97 [citations omitted].

102. See notes 82 \& 83 supra and accompanying text.

103. 407 U.S. at $96-97$.

104. 405 U.S. 56 (1972).

105. Id. at 78.

106. Cf. CaL. Code Civ. Pro. \& 539a (West Supp. 1973), requiring that a plaintiff seeking to attach property of the defendant post an undertaking in an amount equal to at least one-half of the ontstanding obligation to compensate the defendant for damages caused by the restraining order or writ of attachment. The bond required of the plaintiff who has been successful in his motion for a preliminary injunction is not as onerous because there is no minimum amount. 
courts will review. ${ }^{107}$ However, the whole procedure does not thereby become unconstitutional. The courts are competent to police themselves to prevent abuse of the rights of litigants, and it is unlikely that they would formulate procedures which deny due process to debtors. The preliminary injunction is issued in order to preserve the status quo pending a trial on the merits; ${ }^{108}$ if the injunction defendant later prevails on the merits, he may have suffered damage in the interim. The requirement of bond to compensate the defendant in the event he is damaged adjusts the rights of the parties. The amount of bond is set by the court and is determined by the potential amount of damage to the defendant from the preliminary injunction. The bond in a preliminary injunction should be sufficient to recompense the trustee for damages resulting from the delay in the sale, including diminished value of the property if the fair inarket value is reduced between the time the preliminary injunction is issued and final judgment in the injunctive suit. ${ }^{109}$ If the amount of the bond is so great as to bear no reasonable relationship to the potential damage to the trustee, the bond requirement may be too onerous. ${ }^{110}$ There is no doubt, however, that a rationally related bonding requirement satisfies constitutional requirements. ${ }^{111}$

To impose an injunction on one party without making provision for compensating him for damages if he should prevail might itself raise questions of constitutional dimension. ${ }^{112}$ An injunction by its nature is a harsh remedy, and if there were no bond requirement the possibilities for abuse by plaimtiffs would be enormous.

California has mitigated the potential financial burden on the

107. To the extent that the debtor must post other property as security for the bond, excessive bond requirements might be analagous to prejudgment attachment. See note 65 supra. See also Jones Press, Inc. v. Motor Travel Serv., Inc., 286 Min. 205, 176 N.W.2d 87 (1970) (bond requirements which exhaust debtor's credit violate constitutional requirements as set out in Smiadach v. Family Finance Corp., 395 U.S. 337 (1969)).

108. State Bd. of Barber Examiners v. Star, 8 Cal. App. 3d 736, 738, 87 Cal. Rptr. 405, 451 (4th Dist. 1970); Oksner v. Superior Court, 229 Cal. App. 2d 672, 687, 40 Cal. Rptr. 621, 631 (2d Dist. 1964); Sachs v. Killeen, 165 Cal. App. 2d 205, 331 P.2d 735 (2d Dist. 1958).

109. For a discussion of damages for which the trustee may be recompensed from the bond if he prevails in the litigation, see Surety Savings \& Loan Ass'n v. National Automobile Cas. \& Ins. Co., 8 Cal. App. 3d 752, 87 Cal. Rptr. 572 (4th Dist. 1970).

110. See Jones Press, Inc. v. Motor Travel Serv., Inc., 286 Min. 205, 176 N.W.2d 87 (1970).

111. See note 105 supra and accompanying text.

112. Cf. Lindsey v. Normet, 405 U.S. 56 (1972). In discussing the Oregon requirement that the "tenant provide for accruing rent pending judicial settlement of his disputes with the lessor," the Court noted appellants' concession at oral argument that the absence of this requirement might result in a deprivation of the landlord's property withont due process of law. Id. at 66-7 n.13. 
trustor in bringing his injunctive action through the provisions of Civil Code section $1717 . .^{113}$ This section requires that the prevailing party be reimbursed for attorney's fees, costs, and "reasonable disbursements" in the event that the underlying contract requires reimbursement by either party. All standard trust deeds contain such a provision in favor of the trustee. Since disbursements for the purpose of obtaining a bond in an injunction suit would logically fall within the reasonable disbursements category, the trustor will be compensated for his expenditures required to maintain the action if he prevails in a suit for a final injunction. Thus, even though the bonding requirement does not appear to present constitutional problems, possible inequity between the trustor-plaintiff and the trustee-defendant is further alleviated in California. If the trustor does not prevail, the bond stands as a fund from which the trustee may obtain compensation for damages suffered, a safeguard for the trustee which the above analysis indicates is entirely reasonable.

The trustor does not have to post a bond in order to obtain a hearing on his motion for a preliminary injunction, however. The hearing on the motion provides the pre-taking fair hearing which the Supreme Court has mandated in Sniadach, Goldberg, Fuentes and other cases. This hearing obviously is adequate to prevent "unfair and mistaken deprivations of property," the fundamental reason for the requirement, ${ }^{114}$ since it makes available to the trustor the full equitable powers of the court. ${ }^{115}$ Once this hearing has been held, the imposition of a bond as a condition to granting the injunction represents a rational determination by the legislature that this is a reasonable way of adjusting the rights of the parties. The Supreme Court has explicitly approved judicial deference to such a determination by the legislature after the threshold due process requirements are met. ${ }^{116}$

\section{Setting Aside the Sale}

Even if the trustee does not avail himself of his opportunity for a pre-sale hearing, he may institute a suit to set aside the sale after it has been held. The sale may be set aside for failure to comply with the provisions of the statute, or if the purchaser is the trustee or a person or institution in which the trustee has a financial interest, ${ }^{117}$ or for any other reason which the court may find sufficient in its equitable dis-

113. Cal. CIv. CODE $\$ 1717$ (West Supp. 1973).

114. Fuentes v. Shevin, 407 U.S. $67,81,97$ (1972).

115. See note 101 supra and accompanying text.

116. See note 103 supra and accompanying text.

117. Copsey v. Sacramento Bank, 133 Cal. 659, 66 P. 7, 204 (1901); Karlsen v. American Savings \& Loan Ass'n, 15 Cal. App. 3d 112, 92 Cal. Rptr. 851 (2d Dist. 1971). 
cretion. Although the availability of the suit for an injunction is sufficient to satisfy constitutional requirements, and the availability of the suit to set aside alone might not meet the constitutionally mandated requireinent for notice and opportunity for a pre-deprivation hearing, the elements of the action to set aside illuminate both the competing interests of the parties which are sometimes present in a foreclosure context and the ability of the courts to balance them.

In order to set aside the sale, the debtor must "do equity" and tender the amount of the obligation. ${ }^{118}$ In explanation of this requirement the court in Leonard v. Bank of America said:

Equity will not interpose its remedial power in an idly and expensively futile act, nor will it purposely speculate in a field where it has no proof as to what beneficial purpose may be subserved through its intervention. ${ }^{119}$

Unless the plaintiff in the suit tenders the full amount of the obligation owing, the court might find itself in the position of setting aside the sale only to have the litigation commence again, as the creditor again seeks to be paid. ${ }^{120}$ A procedural error in the conduct of the sale, or a financial relationship between the purchaser and the trustee, although they may present equitable issues which make the sale voidable, should not be sufficient to void the sale unless the trustor shows that he is able to pay the hquidated debt which he owes. Although the trustor who must offer to pay the obligation in order to set the sale aside is disadvantaged, the court must balance this disadvantage against that the unpaid creditor faces if he is denied payment for another protracted period.

In Karlsen v. American Savings \& Loan Association ${ }^{121}$ the debtor sought to set aside the sale, claiming that he would tender payment at a later time upon such terms as the court might declare to be reasonable. In that case the trustee and the beneficiary had postponed the sale four times while the trustor attempted to find a means of refinancing his purchase. He was unsuccessful, and the trustee refused to reconvey a portion of the property so that the trustor might in turn sell it to obtain cash for further payments. There was no provision in the

118. Hauger v. Gates, 42 Cal. 2d 752, 269 P.2d 609 (1954); Shimpones v. Stickney, 219 Cal. 637, 28 P.2d 673 (1934); Karlsen v. American Savings \& Loan Ass'n, 15 Cal. App. 3d 112, 92 Cal. Rptr. 851 (2d Dist. 1971); Crummer v. Whitehead, 230 Cal. App. 2d 264, 268, 40 Cal. Rptr. 826, 829 (1st Dist. 1964); Py v. Pleitner, 70 Cal. App. 2d 576, 582, 161 P.2d 393, 396 (1st Dist. 1945); Leonard v. Bank of America, 16 Cal. App. 2d 341, 344, 60 P.2d 325, 326-27 (1st Dist. 1936); American Trust Co. v. DeAlbergaria, 123 Cal. App. 76, 10 P.2d 1016 (1st Dist. 1932).

119. 16 Cal. App. 2d 341, 344, 60 P.2d 325, 326-27 (1st Dist. 1936).

120. Karlsen v. American Savings \& Loan Ass'n, 15 Cal. App. 3d 112, 118-19, 92 Cal. Rptr. 851, 855 (2d Dist. 1971).

121. 15 Cal. App. 3d 112, 92 Cal. Rptr. 851 (2d Dist. 1971). 
agreement calling for early reconveyance of any portions of the property. In giving effect to the sale the court pointed out that to permit the trustor to offer, in effect, "substitute tender"122 and to pay upon some terms dictated by the court would lead to protracted litigation, grant the trustor an indefinite option to purchase the property over a period of changing market value, ${ }^{123}$ and leave the creditor virtually without a remedy - with neither the payments nor the property. ${ }^{124}$ The court obviously did not feel it was within its equitable discretion to do something which would amount to a substantial rewriting of the terms of the original sale contract. Moreover, the trustor would have been able to appeal the terms of any payment schedule which the court might find reasonable, ${ }^{125}$ and the resulting litigation would be unjustifiably expensive and burdensoine to the courts and to the parties.

In balancing the lardship on the defaulting debtor against the creditor's right to be paid, and including in the equation the courts' interest in disposing efficiently of the suits before thein, it seeins reasonable not to permit the debtor to rely on procedural deficiencies in the conduct of the sale to escape payment of his debt for an indefinite period. The court's giving effect to the sale in such a situation does not constitute an unconstitutional deprivation of the trustor's right to due process of law.

Moreover, the burden on the debtor imposed by the tender requirement is ameliorated by the equitable nature of the suit to set aside the sale, and the court may exercise its discretion to set aside the sale without tender if it finds that the debtor would be inequitably burdened by such a requirement. In Humboldt Savings Bank $v$. McClaverty ${ }^{126}$ the Califorma Supreme Court said:

[T]t is certainly not the law that an offer to pay the debt must be made, where it would be inequitable to exact such offer of the party complaining of the sale. . . . It has always been the pride of courts of equity that they will so mould and adjust their decrees as to award substantial justice according to the requirements of the varying complications that may be presented to them for adjudication. ${ }^{127}$

The court indicated that if the debtor has paid the debt, or has not defaulted in his payments due, the sale would be set aside without a requirement of tender. The courts seldoin find it necessary to deal with this problem, because in most cases the trustor is in default and

122. Id. at $120,92 \mathrm{Cal}$. Rptr. at 856 .

123. Id.

124. Id.

125. Id. at 120, 92 Cal. Rptr. at 855 .

126. 161 Cal. 285, 119 P. 82 (1911).

127. Id. at $291-92,119 \mathrm{P}$. at 84-85. 
seeks to mitigate his default by claiming an offset. It is doubtful in the latter situation whether the debtor eventually would pay or not, and the court's reasonable balancing of the equities between the parties indicates that there should be tender. In situations where the trustee has behaved unconscionably and sold the property where all payments have been made as they became due, it is well within the equity powers of the courts to reinstate the obligation and set aside the sale. In such a situation, the trustor may depend on the court to do justice as between the two parties. Any unconscionable or unfair action on the part of the trustee can be raised, such as prior reinstatement of the obligation or tender of reinstatement. ${ }^{128}$ If such claims were proved, the trustee's sale would be held in violation of the terms of section 2924, and a different situation would be presented than when the sale's shortcomings are only procedural.

It is true that the trustor must bear the burden of acting as plaintiff in the suit to set aside, and the burden of proof of such issues as he may raise is on him, but these burdens do not reach a level of constitutional denial of due process. ${ }^{129}$ The same arguments apply to the suit to set aside as to a suit for an injunction. To the extent that the trustor believes that the trustee lias sold the property in violation of their agreement, it is his traditional role as the aggrieved party to seek adjudication of his rights by the court. The issues which he must prove to set the sale aside are the same which he would have to prove as the defendant in a judicial foreclosure. On a factual issue, such as payments already made, the standard of proof probably will not differ significantly, and the court of equity may adjust the balance to do justice between the parties.

Civil Code section 2924 provides that a recital of compliance with the notice requirements of the statute constitutes "conclusive evidence thereof in favor of bona fide purchasers and encumbrancers for value and without notice."130 If the trustor does receive notice, he can file a notice of lis pendens ${ }^{131}$ and thereby prevent any purchaser from claiming lack of notice, so that the conclusive presumption of the statute will be ameliorated. It is arguable that the presumption operates only as to compliance with the statutory requirements, and that there is no presumption of validity of the sale if the trustee has sold the property wrongfully, i.e., if the trustor is not in default. However, traditionally the title of a bona fide purchaser is protected, and the court would have to consider the rights of this third party in determining whether to set aside the sale. Because this situation could

128. Py v. Pleitner, 70 Cal. App. 2d 576, 581, 161 P.2d 393, 396 (1st Dist. 1945).

129. See notes 67-74 supra and accompanying text.

130. Cal. Civ. Code $\S 2924$ (West Supp. 1973).

131. Cal. Code Civ. Pro. $\S 409$ (West 1967). See note 162 infra. 
occur if the trustee were able to escape his duty to give notice, the argument that the legislature should amend the statute to require actual notice is strengthened. Of course, the problem arises primarily when the trustor claims that he was not in default in his payments or that the obligation was fully paid. Otherwise, his failure to make payments would put him on notice that the trustee was likely to take action, and the constructive notice required by the statute ${ }^{132}$ would probably be satisfied.

\section{IV.}

\section{A Fatr Balance of Competing Interests}

The package of procedures and remedies which constitute the state's regulation of the private trustee's sale can be interpreted as the result of a legitimate and rational legislative balancing of the interests of the parties. These interests include, but are not limited to, the trustor's due process interests and the trustee's interest in liavimg a private remedy for default in the obligation which underlies any deed of trust. Indeed, as the following discussion will demonstrate, the counterbalancing of advantages and disadvantages to both parties accomplished by this package of state regulation succeeds in being evenhanded and fair to both, as well as in promoting legitimate state interests. As such, it stands as a legislative determination to which it is entirely appropriate that the courts defer.

The trustor assumes a burden in becoming the plaintiff in an equitable action either to restrain the sale by means of an injunction or to set aside the sale after it has been held. The risk of nonpersuasion shifts to him to prove that he is not in default. He faces threshold problems of ripeness and standing which must be overcome before he can successfully maintain a suit for an injunction.

These burdens imposed on the trustor do not reach a level of constitutional defect. While the Supreme Court has refused to give effect to statutes which placed the burden of proof on a private imdividual rather than the state, those cases have involved sucli highly valued constitutional rights as freedoin of speech and the right to vote. Once the trustor lias obtained his opportunity for a hearing, which is clearly available for him under the scheme of remedies in California, he does not have a constitutional right to be a defendant rather than a plaintiff. ${ }^{133}$

This is not a case, moreover, where the role of plaimtiff and the burden of initiating the action is moved by statute from the state to an

132. See text accompanying note 31 supra.

133. See notes 67-74 supra and accompanying text. 
individual. ${ }^{134}$ The trustee's sale involves private action between two parties; insofar as one person feels aggrieved by the actions of another, it is traditional that he must carry the plaintiff's burdens. If the trustee violates his contractual right to sell only in the event of default, it is the trustor who must move to enjoin the breach which nay result in irreparable harm to him. In any private disagreement, one of the two parties must initiate action. While constitutional requirements of fairness may demand that it be the creditor who must initiate action when he uses the machinery of the state's institutions ${ }^{135}$ such as the sheriff's office to repossess property of the debtor, nevertheless when the debtor is not denied use of the property until at least 110 days have elapsed, ${ }^{136}$ and when the trustor has ample opportunity to appear in court to protect his rights, there is no compelling reason why the state should determine the posture in which the parties will appear before the court.

The threshold burdens of proving ripeness and standing and imminence of irreparable harm ${ }^{137}$ are unlikely to present a problein for the trustor who has a valid reason for complaining of the trustee's action. Insofar as the trustor's claim that he is not in default is valid, the danger that his property will be sold to satisfy the debt represents sufficient potential harm so that the court would not deny an injunction.

As plaintiff, the trustor would have to prove that he is not in default; he probably would have to carry the risk of nonpersuasion on this issue in a judicial foreclosure action once the trustee or creditor had established proof of default, particularly if the issue of payment involves a claim of offset. The issue of failure to make payments is a fairly factual one, and the elements of proof would probably be the same whether the trustor were plaimtiff or defendant. Thus the risk of

134. See the cases cited in notes $67 \& 68$ supra. All involve situations in which an individual is forced to challenge the state in order to obtain a judgment that some action of his is constitutionally protected.

135. See Fuentes v. Shevin, 407 U.S. 67 (1972); Blair v. Pitchess, 5 Cal. 3d 258, 486 P.2d 1242, 96 Cal. Rptr. 42 (1971) for examples of state involveinent in the taking. For discussion of contractual provisions for private repossession under the Uniform Commercial Code, see Dunham, Due Process and Commercial Law, 1972 Sup. Cr. Rev. 135, 147-55, and Brunswick Corp. v. J\&P, Inc., 424 F.2d 100 (10th Cir. 1970).

136. Three months between recordation of the notice of default and notice of sale, CAL. Crv. CODE $\$ 2924$ (West Supp. 1973), plus 20 days which unust then elapse before the sale inay take place, CAL. Crv. CoDE $\$ 2924 \mathrm{~b}$ (West 1970). Cf. Young v. Ridley, 309 F. Supp. 1308 (D.D.C. 1970) (30-day period is sufficient).

137. Cal. Code Civ. Pro. $\$ 526$ (West 1967) codifies the reqnirements for standing to enjoin the conduct of another party. Real property is traditionally considered to be a nonfungible asset. Its imminent loss is held not conpensable in damages at common law but a breach of a contract to convey will often result in a remedy of specific performance. 
nonpersuasion is not significantly greater for the trustor in the suit to enjoin the sale. Indeed, in the hearing on the trustor's motion for a preliminary injunction, the trustor need only prove that there is a reasonable likelihood that he will prevail and that the status quo should be preserved pending a trial on the merits. ${ }^{138}$

The private sale offers the trustor certain advantages to offset these disadvantages. The most obvious is that if he is in default the trustor may be foreclosed and may vacate the property and acquiesce in the validity of the sale without becoming involved in a legal action. Despite the fact that the proceeds from the sale are applied to pay the trustee's fees and the costs of the sale, ${ }^{189}$ these inay be considerably less than the creditor would incur in a judicial foreclosure. ${ }^{140}$ Since most security agreements contain a provision for payment of the creditor's legal fees and costs if the creditor should prevail in an action by the creditor arising from the contract, the debtor would be liable for fees incurred in the judicial foreclosure, even if the debtor elected to take a default judgment. Conversely, the fees of the debtor who prevails in a suit for injunction will be paid by the creditor. ${ }^{141}$ This financial advantage, combined with the desirability of staying out of court when judicial intervention is unnecessary, inake the trustee's sale desirable to many trustors.

A concomitant advantage accrues from the requirement that after the notice of default is recorded the trustee may not file his notice of sale for 90 days; ${ }^{142}$ during that period the trustor lias an opportunity

138. See CAL. Code Crv. Pro. $\$ 527$ (West Supp. 1973); State Bd. of Barber Examiners v. Star, 8 Cal. App. 3d 736, 738, 87 Cal. Rptr. 450, 451 (4th Dist. 1970), where the court of appeal said:

Generally, a preliminary injunctive order does not reach the merits of the permanent injunctive relief sought in the complaint. The court, at this stagc, balances the equities of the parties and determines whether the defendants should be restrained from exercising the right claimed by them pending a trial on the merits. The general purpose is to preserve the status quo until the merits of the action are determined. The court considers who will bear the greater injury should the preliminary injunction be granted and whether a reasonable probability exists the plaintiff will prevail.

See also Continental Baking Co. v. Katz, 68 Cal. 2d 512, 528, 439 P.2d 889, 899, 67 Cal. Rptr. 761, 771 (1968); Flavio v. McKenzie, 177 Cal. App. 2d 274, 279, 2 Cal. Rptr. 79, 83 (1st Dist. 1960).

139. These fees become part of the obligation, to which the proceeds of the sale are applied. Cf. CAL. Crv. CODE $\$ 2924 c$ (West 1970), stating that the trustor must pay these fees in order to reinstate the obligation during the 90 days between notice of default and notice of sale.

140. For a comparison of the costs of judicial and nonjudicial foreclosure nationwide, see Comment, Power of Sale after Fuentes, 40 U. CHr. L. Rev. 206, 210-13 (1972), and data cited therein.

141. Under CAL. CTv. CODE $\$ 1717$, if the security agreement calls for one party to pay the other's fees in the event the latter prevails, the provision will be euforced reciprocally.

142. CaL. Civ. CODE $\S 2924$ (West Supp. 1973). 
to reinstate the obligation by payment of only the installments then due. The trustor can try to renegotiate the loan with the beneficiary, or he can attempt to obtain refinancing elsewhere. The trustee is free to postpone the sale without court permission if he finds that the trustor is making good faith efforts to raise the inoney. Even for the trustor who is in default, admits it, and realizes that he cannot enjoin the sale, this 90-day period is valuable for the opportunities it gives him to explore ways of keeping his property.

After the sale is held, the trustee cannot obtain a personal judgment against the trustor for any part of the obligation which remains unsatisfied by the proceeds of the sale, since Code of Civil Procedure section $580 \mathrm{~d}$ forbids any deficiency judgment following a private sale of the security. ${ }^{143}$ This prohibition is a trade-off for the absence of a statutory period of redemption following a private sale. ${ }^{144}$ However, following a judicial foreclosure of a security instrument which contains a power of sale, the period of redemption is three months. ${ }^{145}$ The 90-day period before the trustee may record his notice of sale provides the saine amount of time for the trustor to attempt to pay the obligation, and he enjoys the advantage of paying without acceleration. ${ }^{14 a}$

There are correlative advantages and disadvantages to the creditor from use of the judicial sale procedure. Since it is the creditor who inakes the election to lave a trustee's sale rather than judicial foreclosure at the time of default, however, the trustee can choose judicial sale whenever the disadvantages are de minimis. In some situations, a trustee's sale may take longer than a judicial foreclosure, because in the latter case a default judgment may be obtained faster than the 90-days-plus waiting period before sale by the trustee. The creditor who sells the property at a private sale loses his right to a deficiency judgment, ${ }^{147}$ and during the 90 -day period following recordation of the notice of default the debtor may reinstate without acceleration. ${ }^{148}$ Filing of a complaint in judicial foreclosure puts an end to this right. ${ }^{149}$

There are advantages to the creditor from the procedure, obviously, or he would not make use of it. However, these advantages do not mean that the creditor is able to use the procedure unconscionably to deprive the trustor of his property. The advantages come from the

143. Cal. Code Crv. Pro. $\$ 580 \mathrm{~d}$ (West 1967).

144. Roseleaf v. Chierighino, 59 Cal. $2 d$ 35, 43, 378 P.2d 97, 101-02, 27 Cal. Rptr. 873, 877-78 (1963).

145. Cal. Code Crv. Pro. § 725a (West 1967).

146. Cal. Crv. Code $\$ 2924 \mathrm{c}$ (West 1967).

147. Cal. Code Civ. Pro. $\$ 580$ d (West 1967).

148. Cal. Civ. Code $\$ 2924 c$ (West 1970).

149. See CAL. CTv. CODE $\$ 2932$ (West 1970). 
simplicity of the procedure-staying out of court and settling the problem of the default privately. ${ }^{150}$ Since the trustee is seldom able to avoid giving actual notice, use of the private sale does not eliminate all opportunities for the trustor to have a hearing. ${ }^{151}$ The trustee must balance the advantages and disadvantages before he decides how to foreclose. It must be remembered that not all foreclosures in California are by nonjudicial sale; judicial foreclosure, with its attendant periods of redemption and deficiency judgments, is often used. ${ }^{152}$

The trustee may act erroneously, or even maliciously and fraudulently in recording a notice of default. If he has made a good faith mistake, the notice required to be sent to the trustor will provide ample opportunity to cure the mistake through private action, or an injunction suit, if need be. If the trustee is acting fraudulently or maliciously, the situation is analogous to any in which an individual does intentional harm to the interests of another: our legal system has specific tools and remedies at the disposal of the aggrieved party to repair and sanction the wrongdoing, ${ }^{153} \mathrm{~m}$ addition to those provided by the requirements of notice and opportunity for hearing. For instance, the constitutional requirements of notice and opportunity for hearing

150. The state's interest in encouraging private dispute settlement, rather than forcing all persons to litigate their differences, is the same.

151. The court can exercise its equitable powers to adjust the interests of the parties if this does occur. Insofar as the current notice provisions are not designed to provide actual notice, they should be changed. See discussion of notice in the text accompanying notes $22-57$ supra.

152. Two situations in which judicial foreclosure may be the preferred remedy for the trustee are: (1) where the trustee knows his claim of default is in dispute, e.g., when he is claiming default on some aspect of the underlying contract other than payment, the trustee may prefer to initiate judicial determination rather than waiting for the almost inevitable injunctive action or suit to set aside; (2) where other disputes over the underlying contract are at issue, the trustee may inclnde an action for judicial foreclosure of the property in order to elininate the time periods and reinstatement options attendant to private sale in the event the litigation finds the trustor is in default. In both instances the advantages to the trustee of having initial control over the contours of the litigation and protecting himself from liability for damages caused by an after-determined wrongful sale outweigh the advantages of the private sale.

153. In the area of real property, the Califorma courts have been sensitive to the potential for impairment of transferability occasioned by intentional interference with the property rights of another. Actions for fraud, dnress, slander of title, and to quiet title, among others, will lie, depending on the facts of the case. See, e.g., Paramount Properties Co. v. Transamerica Ins. Co., 1 Cal. 3d 562, 567, 463 P.2d 746, 749, 83 Cal. Rptr. 394, 397 (1970) (duress, quiet title); Leeper v. Beltrami, 53 Cal. 2d 195, 204-08, 347 P.2d 12, 18-20, 1 Cal. Rptr. 12, 18-21 (1959) (fraud, duress); Gudger v. Mauton, 21 Cal. 2d 537, 134 P.2d 217 (1943) (slander of title); Forte v. Nolfi, 25 Cal. App. 3d 656, 685-87, 102 Cal. Rptr. 455, $474-75$ (1st Dist. 1972) (slander of title); Glass v. Gulf Oil Corp., 12 Cal. App. 3d 412, 419, 96 Cal. Rptr. 902, 906 (1st Dist. 1970) (slander of title); Lenard v. Edmonds, 151 Cal. App. 2d 764, 312 P.2d 308 (1st Dist. 1957), Stockton v. Newman, 148 Cal. App. 2d 558, 307 P.2d 56 (1st Dist. 1957), Daniel v. Willianis, 125 Cal. App. 2d 310, 270 P.2d 556 (1st Dist. 1954) (fraud, and imjunctive relief to prevent sale by the creditor). 
do not protect against forged service of process, perjury, or similar willful illegality, partly because, within certain procedural constraints to ensure fairness and equality, a presumption of some good faith is essential to the functioning of the adjudicative process, and partly for the reason that if good faith is absent, collateral avenues of redress, including possible pumitive danages, exist.

The hearing on a motion for preliminary injunction provides a safeguard against unfair and mistaken private sales, which is the constitutional mandate, ${ }^{154}$ to the extent any pre-taking hearing can. In the usual case of either a default by the trustor or a good faith dispute over terms of the contract underlying the deed of trust, the private sale procedure provides time and opportunity for either private renegotiation or adjudication. The state is under no constitutional compulsion to establish the terms of security agreements, so long as the regulation it does impose does not permit unconscionable dealing ${ }^{155}$ and is a rational balancing of the legitimate interests of the trustor and the trustee. In instances of abuse of the contractual relationship, the courts are coinpetent to adjust the rights of the parties and remedy any incidences of unfairness between them. ${ }^{156}$

The state has strong interests and pohicies in favor of letting parties work out their own differences. The trustee's sale serves this end. The imposition by statute of the 90-day interval between recording the notice of default and recording the notice of sale ${ }^{157}$ indicates this strong policy by permitting the debtor to find ways to meet his obligation without resort to the courts. If the debtor remains unable to pay, the state has expressed a policy in favor of private sale of the property without the cost and possible inefficiency in terms of delay which might be saved the court systein if neither party feels a need to seek adjudication of a dispute. Foreclosure does not necessarily mean that there is a disagreenent; it is entirely possible that the debtor

154. See discussion of the injunction action, in the text accompanying notes 75116 supra.

155. See Williams v. Walker-Thoinas Furniture Co., 350 F.2d 445 (D.C. Cir. 1965): "Unconscionability has generally been recognized to include an absence of meaningful choice on the part of one of the parties together with contract terms which are unreasonably favorable to the other party." Id. at 449 . The advantages to the debtor from the procedure are not so outweighed by disadvantages that the terms unreasonably favor the creditor. The deed of trust is undoubtedly a contract of adhesion, but it does not attain the level of unconscionability which would lead the courts to refuse to give it effect.

156. Of course, the problein will most often be simply a dispute about the obligations of the parties under the terms of the agreement. Such dispute settlement is traditionally within the courts' competence. The equitable powers of the court can be relied upon to prevent serious harm to the debtor by maintaining the status quo pending settlement of the litigation. See note 138 supra.

157. Cax. Civ. CODE $\S 2924$ (West Supp. 1973). 
simply does not have the money to pay and has no way of obtaining it. When this is the case, the state has an interest in not protracting litigation and in leaving dispute settleinent in the hands of the parties.

The state has a further interest in keeping the machinery of the credit industry moving as smoothly as possible, so as to ensure reasonable interest rates. If the creditor must incur the potential expense of obtaining a hearing in every case-meaning expense both in terms of delay and of fees and costs if the debtor is not obliged or is unable to pay-the cost of money will increase. ${ }^{158}$ One federal district court recently commented on this situation when denying effect to the repossession and sale provisions of sections 9503 and 9504 of the Uniform Commercial Code. ${ }^{150}$ The court in that case was forced to hold that the statute was unconstitutional, since the judge felt that it clearly violated the debtor's right to procedural due process, ${ }^{100}$ but he did so reluctantly, because he saw a value in having credit available as cheaply as possible to those who do pay their debts. Requiring a hearing before repossessing the security of those who do not pay will inevitably raise the cost of money. ${ }^{101}$

The statutory regulation of the use of the power of sale to foreclose a real estate interest adequately balances the entire package of creditor and debtor advantages and disadvantages. Moreover, the procedures take into account traditional contract protections which are available to a party whose agreement has been breached by another. These remedies are available to the aggrieved party through the courts. The legislature has constructed a system which enables the trustor to utilize remedies such as injunction and setting aside the sale in the event the trustee attempts to sell wrongfully. By enacting Code of Civil Procedure section 409, the legislature made it possible for the trustor to file a notice of lis pendens and prevent sale by the trustee

158. In Goldberg v. Kelly, 397 U.S. 254 (1970), the Supreme Court said:

[T] he interest of the eligible recipieut in uninterrupted receipt of public assistance, coupled with the State's interest that his payments not be erroneously terminated, clearly outweighs the State's competing concern to prevent any increase in its fiscal and administrative burdens.

Id. at 266. In the case of the trustee's sale there is no question, however, of denying the debtor a hearing before he is deprived of his property. The Court in Goldberg made it clear that the required hearing need not be a judicial, or even quasi-judicial, one. The trustor can obtain a judicial hearing. There is no need, however, for the state to inandate judicial intervention by requiring that the trustee obtain court permission for the sale whether the trustor protests or not.

159. Adams v. Egley, 338 F. Supp. 614, 622 (S.D. Cal. 1972).

160. The case is presently on appeal in the Court of Appeal for the Ninth Circuit.

161. The state has an interest in ensuring the availability of credit to all those who need it in order to purchase homes and other assets. To the extent that those who pay their obligations must (through higher cost of credit) bear the costs of litigation between the creditor and those who do not pay, the interests of all borrowers are disserved by requiring hitigation in every case. 


\section{to a bona fide purchaser pending final adjudication. ${ }^{162}$}

The state has an additional interest in making sure that creditors are repaid; conversely, it has no reason to countenance lengthy delays while frivolous issues are hitigated. The legislative judgment that the creditor must wait ninety days, together with the remedies available to the debtor, combine to adjust the rights of the two parties. ${ }^{163}$

\section{CONCLUSION}

California's statutory regulation of the trustee's sale represents sufficient state action to require that the protections available to the debtor comply with the constitutional mandates of notice and opportunity for hearing. The notice provisions provide adequate notice and permit the debtor to decide whether or not he will seek the intervention of the court to protect himself against the sale.

The equitable proceedings for an injunction and to set aside the sale provide the debtor with an adequate opportunity to obtain a hearing. The hearing can occur before he is deprived of the use of the property, and the nature of the hearing available on a motion for pre-

162. In an action concerning real property or affecting the title or the right of possession of real property, the plaintiff, at the time of filing the complaint, and the defendant, at the time of filing his answer, ... or at any time afterwards, may record in the office of the recorder of the county in which the property is situated, a notice of the pendency of the action. ... Froin the time of filing such notice for record only, shall a purchaser or encumbrancer of the property affected thereby be deemed to have constructive notice of the pendency of the action as it relates to the real property. . . . Cal. Code Crv. Pro. $\$ 409$ (West 1967).

The other party to the action may have the notice of his pendens expunged, but only upon noticed motion and then only if the moving party is able to show by clear and convincing evidence either that the action does not affect title to the property or that the notice was not recorded in good faith. Cal. CoDe Crv. Pro. $\$ 409.1$ (West Supp. 1973). If the moving party succeeds in having the notice expunged, he inust post an undertaking to indemnify the other party against damages in the event the latter prevails in the action. CAL. CoDE CTV. Pro. $\$ 409.2$ (West Supp. 1973). Obviously, this procedure alone provides the trustor with a hearing on the bona fides of his claim.

It should be noted that a Los Angeles County Superior Court has recently declared the notice of lis pendens to be unconstitutional. See Los Angeles Daily Journal, June 12, 1973, page 1, reporting the decision in Lake Tulloch Corp. v. Dingenan (WEC-27140). However, the decision is questionable and unlikely to be sustained if appealed. The statute provides detailed procedures for expunging the notice of lis pendens and these procedures provide a hearing for the party against whom it is filed. Moreover, notice of lis pendens cannot be filed until an action is instituted in some court, and service of process in that action will provide notice of the impending action. On the analysis taken by this Comment, the notice of lis pendens is a reasonable means of protecting the competing interests of both parties while they higate their rights in the property subject to the notice.

163. If the court determines that the trustor's claim for an injunction is frivolous at the hearing for a preliminary injunction, it can deny the motion and allow the sale to proceed. 
liminary injunction satisfies the constitutional requirennents as described in the cases. The burden on the trustor of going to court as plaintiff is not significantly greater than the burden on the defendant in a judicial foreclosure action, since the risk of nonpersuasion which the debtor inust carry is less than that in a full trial on the merits. The constitutional right which is at stake is the right to notice and an opportunity for a hearing, which is protected, not the right to an injunction, which is the subject of the litigation. The debtor does not have a right to the high constitutional protections provided one whose right to freedom of speech is threatened.

The requirement of a bond is a reasonable legislative adjustment of the rights of the parties. The amount of the bond is limited to the damage the creditor may suffer as a result of the injunction, and such a reasonable protection of the value of hitigated property does not violate the constitutional rights of the parties.

The private sale procedure is subject to statutory notice and procedural requirements, to traditional contract protections of fairness, nonadhesion, and unconscionability. The legislative determination that the trustor's opportunity to seek a remedy through the courts is a sufficient opportunity for a hearing represents a rational balancing of the competing interests of the parties to which the court inay defer. In no case do the procedures deprive the debtor of his right to notice and an opportunity for a hearing. No constitutional rights are abridged; thus the court should defer to the legislative judgment that the trustee's sale is a useful and rational way of settling differences between the parties. 